\title{
Visual inventories and field note templates for contextualised recording of human remains
}

Inventaires visuels et modèles de notes de terrain pour l'enregistrement contextualisé des restes humains

\section{Fanny Bocquentin and Marie Anton}

\section{(2) OpenEdition}

\section{Journals}

Electronic version

URL: https://journals.openedition.org/bmsap/7750

DOI: $10.4000 /$ bmsap. 7750

ISSN: $1777-5469$

\section{Publisher}

Société d'Anthropologie de Paris

\section{Electronic reference}

Fanny Bocquentin and Marie Anton, "Visual inventories and field note templates for contextualised recording of human remains", Bulletins et mémoires de la Société d'Anthropologie de Paris [Online], 33 (2) | 2021, Online since 28 September 2021, connection on 29 October 2021. URL: http:// journals.openedition.org/bmsap/7750 ; DOI: https://doi.org/10.4000/bmsap.7750

Les contenus des Bulletins et mémoires de la Société d'Anthropologie de Paris sont mis à disposition selon les termes de la licence Creative Commons Attribution-NonCommercial-NoDerivatives 4.0 International License. 


\section{Visual inventories and field note templates for contextualised recording of human remains}

\section{Inventaires visuels et modèles de notes de terrain pour l'enregistrement contextualisé des restes humains}

Fanny Bocquentin ${ }^{1,2^{*}}$, Marie Anton ${ }^{3,4}$

1. ArScAn, UMR 7041, Équipe Ethnologie Préhistorique, CNRS

2. Laboratoire Cogitamus, Paris

3. École Doctorale d'Archéologie, Université Paris 1

4. Musée de l'Homme, UMR 7206, CNRS

* fanny.bocquentin@cnrs.fr

Reçu : 10 mai 2021 ; accepté : 17 juillet 2021

Bulletins et Mémoires de la Société d'Anthropologie de Paris

\begin{abstract}
This short note is a presentation of seven new visual inventory sheets and five new standardised field note sheets posted on open access. Compared to those currently used in France, our protocols have the advantage of being written in English, for those working outside French-speaking countries. They are also more accurate anatomically and better coverage of specificities by age at death. They have been adapted to bones found in multiple and mixed contexts that cannot be attributed to specific individuals. In the field, they allow archaeo-anthropologists constrained by time to record essential information by taking descriptive notes and drawings.
\end{abstract}

Keywords - fieldwork, inventories, standardized notes, archaeothanatology, bioanthropology

Résumé - Cette courte note est une présentation de sept nouvelles fiches d'inventaires visuelles et de cinq nouvelles feuilles de notes de terrain standardisées en accès libre. Par rapport à celles couramment utilisées en France, elles offrent l'avantage d'être en anglais pour ceux qui travaillent hors pays francophones, d'être plus proches de la réalité anatomique, de mieux couvrir les spécificités par âge au décès. Elles ont également été adaptées aux os non individualisés trouvés en contexte pluriel et mélangé. Sur le terrain elles permettent, aux archéoanthropologues les plus contraints par le temps, d'enregistrer les informations essentielles par la prise de notes descriptives et des schémas.

Mots clés - terrain, inventaires, notes standardisées, taphonomie, archéoanthropologie

\section{Introduction}

This note proposes new visual skeletal inventory sheets and standardised field notes. Accurate inventories of human remains are of major importance, both for bioarchaeology and for the reconstruction of the funerary chaîne opératoire. For biological analysis, they enable accurate estimates of the potential of an assemblage of human skeletal remains. The protocols offer better estimates of the proportions of anatomical segments present or absent in a collection, and thus improved assessments of the true prevalence of observed features (pathology, trauma, discrete traits, metric data, cutmarks etc.). The osteological inventory also makes it possible to discuss absences and excesses of bones and therefore their natural causes (erosion, bioturbation, etc.) as well as the mode of interment of the deceased (multiple deposits, secondary burials, pre- or post-burial removal, cremation, etc.). Meanwhile, standardised notes are designed for efficiency in an excavation context where comprehensive notes cannot be taken due to lack of time. They are mainly intended for use in a rescue context by anthropologists who have to dismantle several skeletons per day. The aim is not to omit essential contextual and taphonomical data but to record what is necessary for a correct reconstruction of the history of a funerary or mortuary deposit. These standardised notes can also be used for less time-pressured excavations. They avoid oversights and the resulting homogenisation of the documentation facilitates data sharing and comparison.

\section{Brief background}

Osteological inventories recorded in databases are essential but the high fragmentation rates of archaeological human remains places limitations on textual descriptions, 
which can be time-consuming and imprecise. This is why visual inventories are often preferred or used in addition by anthropologists. Such visual inventory sheets have been published in the past in the English-language literature (e.g. Meiklejohn and Constandse-Westermann, 1978; Buikstra and Ubelaker, 1994; Roksandic, 2003; Brickley, 2004; Knüsel and Outram, 2004; Baker et al., 2005). In France, visual inventories are used fairly systematically, both for field and laboratory work. The great majority of French anthropologists use the inventories proposed by A.-M. Tillier and H. Duday (1990) and P. Courtaud (1996). These works were published decades ago in this journal. While Tillier and Duday adapted the adult skeleton sheet of Meiklejohn and Constandse-Westermann (1978) for skeletons of perinatal age, Courtaud augmented these two forms with one more suitable for children and adolescents, in whom the secondary ossification centres are not fused. Moreover, he proposed standardized note templates adapted to rescue excavations, where the state of preservation of the major joints can be recorded. Since then, digital recording for anthropologists has been further developed, and the recently published open access software CHumanos (Colleter et al., 2020) is of particular interest.

\section{New sheets for new needs}

Whether in paper or digital form, the existing sheets do not fully meet our expectations, so we have created our own, which hopefully will also be useful to others. These new sheets were created to meet several needs:

- Firstly, when working with English-speaking teams, we had to translate the French-language forms, because they were best suited to the field methods we used, where recording and understanding the taphonomy of the burials is a central concern during excavation (what is currently referred to as field anthropology or archaeothanatology). In this sense, these new English-language forms will be beneficial in stimulating growing interest in this specific field approach, which is still infrequently used abroad.

- Secondly, we were keen to draw the skeletons more closely to anatomical reality than those that already existed, not only for aesthetic reasons but also to provide an effective memo for quick identification and siding of the bones.

- Thirdly, we felt that there was a missing age group - young children between approximately 1 and 7 years of age - for whom the forms proposed so far are not adequate.

- Fourthly, we also need accurate visual records for multiple contexts where bones cannot be attributed to one individual.

- Finally, our context record sheets are suited to the preparation of a rescue excavation with extreme time pressure on the dig and especially on graves (Anton, 2020). We have opted for maximum efficiency by grouping text and drawings together on the same sheet and attempting to simplify taphonomic notes without omitting key concepts and data.

\section{Brief description of the forms}

Twelve new forms are presented here. Four are full-skeleton visual inventory forms adapted to individuals identified during excavation (Appendix 1). Three are individual-bone visual inventory forms for human remains found in multiple mortuary contexts with disarticulated and commingled remains (Appendix 2). The last five forms concern in situ recording of funerary and archaeological contexts together with taphonomical data gathered from graves (Appendix 3).

The individual visual inventory forms represent dismantled bones of a full skeleton, as they are usually observed during lab work, lying on a working table. Thus, some bones are presented in the standard anatomical position but others are not because other viewing planes are more suitable for identification, siding and complete drawing. Only the cranium is represented from different planes, in order to provide the most accurate inventory of its large volume. The legend provides for the addition of qualitative information (e.g. side unknown, fragmentary, crushed, sampled). Text boxes enable the analyst to give numbers of fragments or pieces in cases of imprecise identification (vertebrae, phalanges). The different forms correspond to four age categories: adult, older child and adolescent (all secondary ossification centres present but unfused), young child (ca. 1-7 year-old at death: all bones present and some epiphysis already present, shape of the bones well defined; permanent teeth in development), and perinatal and older infant (ca. 7 months IU-12 months after birth: cranium unfused). For the two last age categories, ribs and vertebrae are not drawn on the standard form but the inventory can be augmented in adjacent boxes, as already proposed by Tillier and Duday (1990).

The isolated-bone visual inventory form is organized by categories: axial bones and teeth; upper limbs, lower limbs. The bones are repeated several times, each corresponding to a potential new individual. The bones drawn facilitate the work of counting the Minimal Number of Individuals and matching/excluding antimeres. Each isolated bone is associated with a blank box in which to write its field identification number. For less diagnostic elements and/or usually highly fragmented bones such as vertebrae, ribs or phalanges, drawings are not available but numerical inventories are proposed in boxes. These sheets are provided for mature bones but the drawings can be recycled from the previous forms for other age categories if necessary.

The note templates are organized as follows: first page for contextual information; second page for general data on the deposit of the corpse; third to fifth pages for the exposed side of the bones and taphonomical data for the skeleton (axial, upper limbs, lower limbs). These data relate to the degree of articulation of the main joints. We opted to use three degrees for recording: "articulated" (the bones involved 
in the joint had not moved since the decay process); "anatomical proximity" (the bones involved in the joint are close to their anatomical relationship or epiphyses are missing but their anatomical coherence is preserved); and "disarticulated" (significant movement of the bones is observed and must be described in the adjacent box: direction, modality, possible cause). Specific glossary terms such as "lateral constraints" "flattening of the rib cage", "disjunction of the vertebral column", "linear effect" "verticalization of the clavicle" etc. refer to the systematised approach to the taphonomy of burials developed by Duday (e.g. 2009). Operators should ideally familiarise themselves with this work before using the current forms, otherwise confusion may occur. The current forms are descriptive only. The purpose of recording the displacement of bones in the grave from their expected anatomical position is to identify distortions related to the evolution of the grave over time, whether due to decomposition of the corpse or other elements of the grave, or to later reopenings or non-anthropogenic disturbances. Once these distortions have been identified and summarized, it is possible to propose a reconstruction of the deposition of the corpse in the tomb, the existence of a non-perennial container, other architectural features and associated items as well as their disposition and relationship to each other in the grave before the observed collapses. The note templates proposed here take an average of 15 to 25 minutes to be completed in the field and the same amount of time is needed to make correct schematic scale drawings. About 45 minutes are therefore needed per burial to obtain a high-quality textual and visual record. This needs to be completed with other type of records such as multi-angled photographs including ortho-photographs, photogrammetry, altitude plots, additional notes on non-articulated joints and drawings in plan view, if possible.

\section{Source files in open access}

It is hoped that these sheets will be regularly reworked and improved, according to the needs of each anthropologist and for the use of the greatest number of users. This is why we are offering the (C) $p d f$ and the CIllustrator (CS6) source versions in open access. We also associate svg files which can be opened with free software such as CInkscape but without allowing full retrieval of the vector drawing. The (C) $p d f$ version is more particularly suited to the field or lab work phase where the equipment, time or weather conditions would not allow work to be carried out directly with the digital versions. While the presence of tablets and computers in the field is becoming more widespread, these tools are unsuitable for certain sites and can even be a cause of lost time. These files are in A4 size and we advise users to uncheck the "fit to page" box at the time of printing so that the millimetric grids remain at the correct scale. The CIllustrator versions of the sheets are intended to be used to produce a clean copy of the data for a report, database or publication. It is strongly advised to start the visual bone inventories by copying and pasting the proposed layout onto a new layer, then locking the original layer to keep it safe. It is then possible to modify the layout, bone by bone for instance with the pathfinder tool, which makes this operation quick and easy. This will result in a partially shaded skeleton relating to the preserved assemblage of bones (see for instance Bocquentin et al., 2020). Any suggestions for modifications or integration into software are welcome, provided that this article is cited.

\section{Acknowledgements}

The authors would like to thank Dr. Phillip Edwards who kindly corrected the English version of this article and the two anonymous reviewers for their constructive comments.

\section{References}

Anton M (2020) Death at Motza: Variability in the treatment of human remains. In: Khalaily H, Re'em A, Vardi J et al (eds) The Mega Project at Motza (Moza): The Neolithic and Later Occupations up to the $20^{\text {th }}$ Century. New Studies in the Archaeology of Jerusalem and Its Region Israel Antiquities Authority, Jerusalem, pp 201-222

Baker BJ, Dupras TL, Tocheri MW (2005) The Osteology of Infants and Children. Texas A\&M University Press, College Station, $188 \mathrm{p}$

Bocquentin F, Anton M, Berna F et al (2020) Emergence of corpse cremation during the Pre-Pottery Neolithic of the Southern Levant: A multidisciplinary study of a pyre-pit burial. PLOS ONE 15:e0235386 [https://doi.org/10.1371/journal. pone.0235386]

Brickley M (2004) Compiling a skeletal inventory: articulated inhumed bone. In: Brickley M, McKinley JI (eds) Guidelines to the Standards for Recording Human Remains. British Association for Biological Anthropology and Osteoarchaeology, IFA Paper No. 7, Berkshire, pp 6-7

Buikstra JE, Ubelaker DH (1994) Standards for Data Collection from Human Skeletal Remains. Arkansas Archeological Survey research series No. 44, Fayetteville, $206 \mathrm{p}$

Colleter R, Romain J-B, Barreau J-B (2020) Humanos: An open source nomadic software database for physical anthropology and archaeology. Virtual Archaeology Review 11(23):94-105 [https://doi.org/10.4995/var.2020.13422]

Courtaud P (1996) “Anthropologie de sauvetage" : vers une optimisation des méthodes d'enregistrement. Présentation d'une fiche anthropologique. Bulletins et Mémoires de la Société d'Anthropologie de Paris 8(3-4):157-167

Duday H (2009) The Archaeology of the Dead. Lectures in Archaeothanatology. Oxbow Books, Studies in Funerary Archaeology, Oxford, $230 \mathrm{p}$

Knüsel CJ, Outram AK (2004) Fragmentation: The zonation method applied to fragmented human remains from archaeological and forensic contexts. Environmental Archaeology 9: 85-97

Meiklejohn C, Constandse-Westermann TS (1978) The human skeletal material from Swifterbant, Earlier Neolithic of the Northern Netherlands. I: Inventory and demography. Palaeohistoria 20:39-89 
Roksandic M (2003) New standardised visual forms for recording the presence of human skeletal elements in archaeological and forensic contexts. Internet Archaeology 13 [http://intarch.ac.uk/ journal/issue13/roksandic_index.html]

Tillier A-M, Duday H (1990) Les enfants morts en période périnatale. Bulletins et Mémoires de la Société d'Anthropologie de Paris 2(3-4):89-98 


\section{Appendices}

(downloadable version at https://journals.openedition.org/bmsap/7828?file=1)

Appendix 1. Dismantled bones of full skeletons of different ages at death: mature (all bones fused), immature (major epiphysis unfused), young child and infant age categories

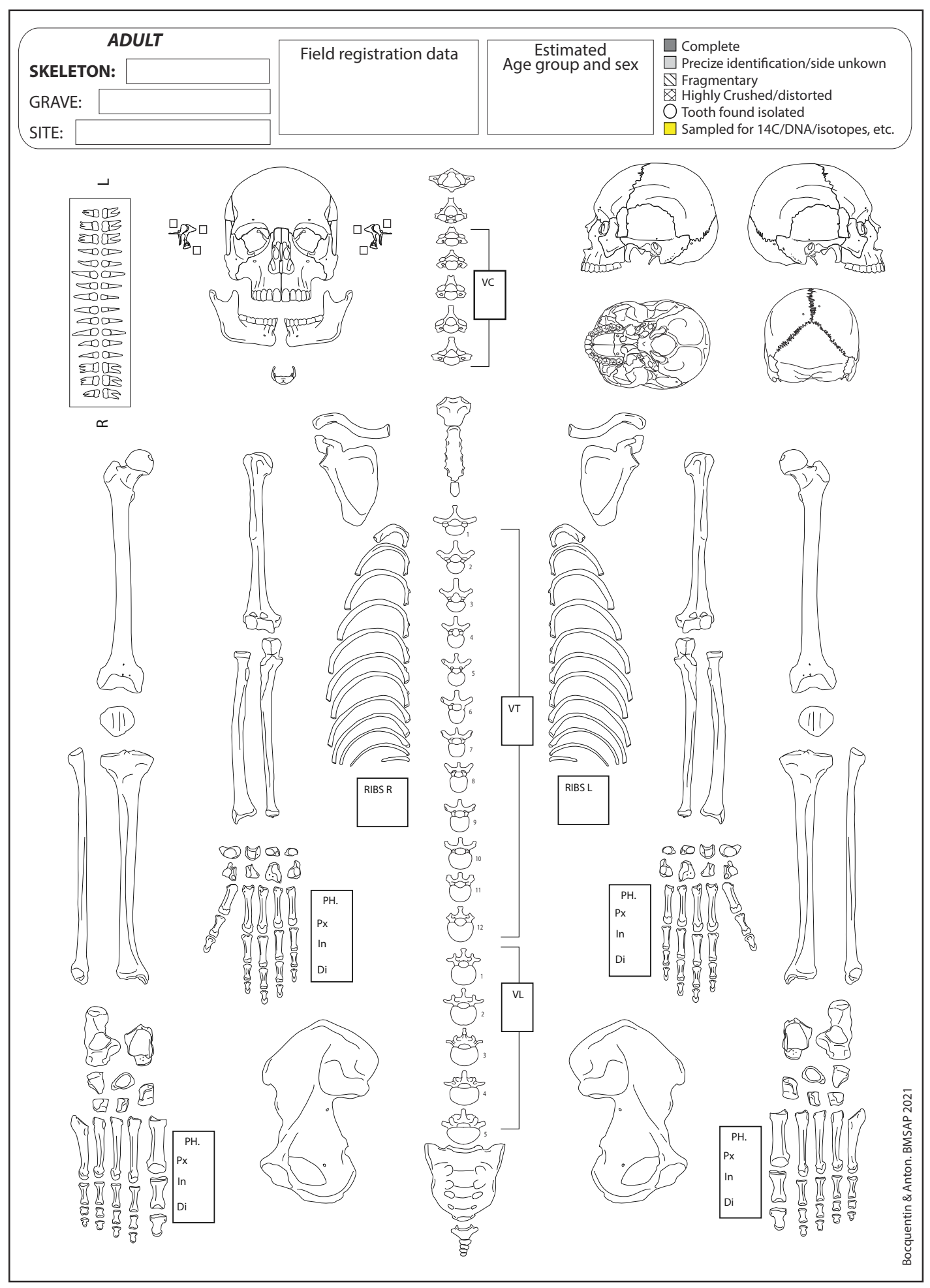




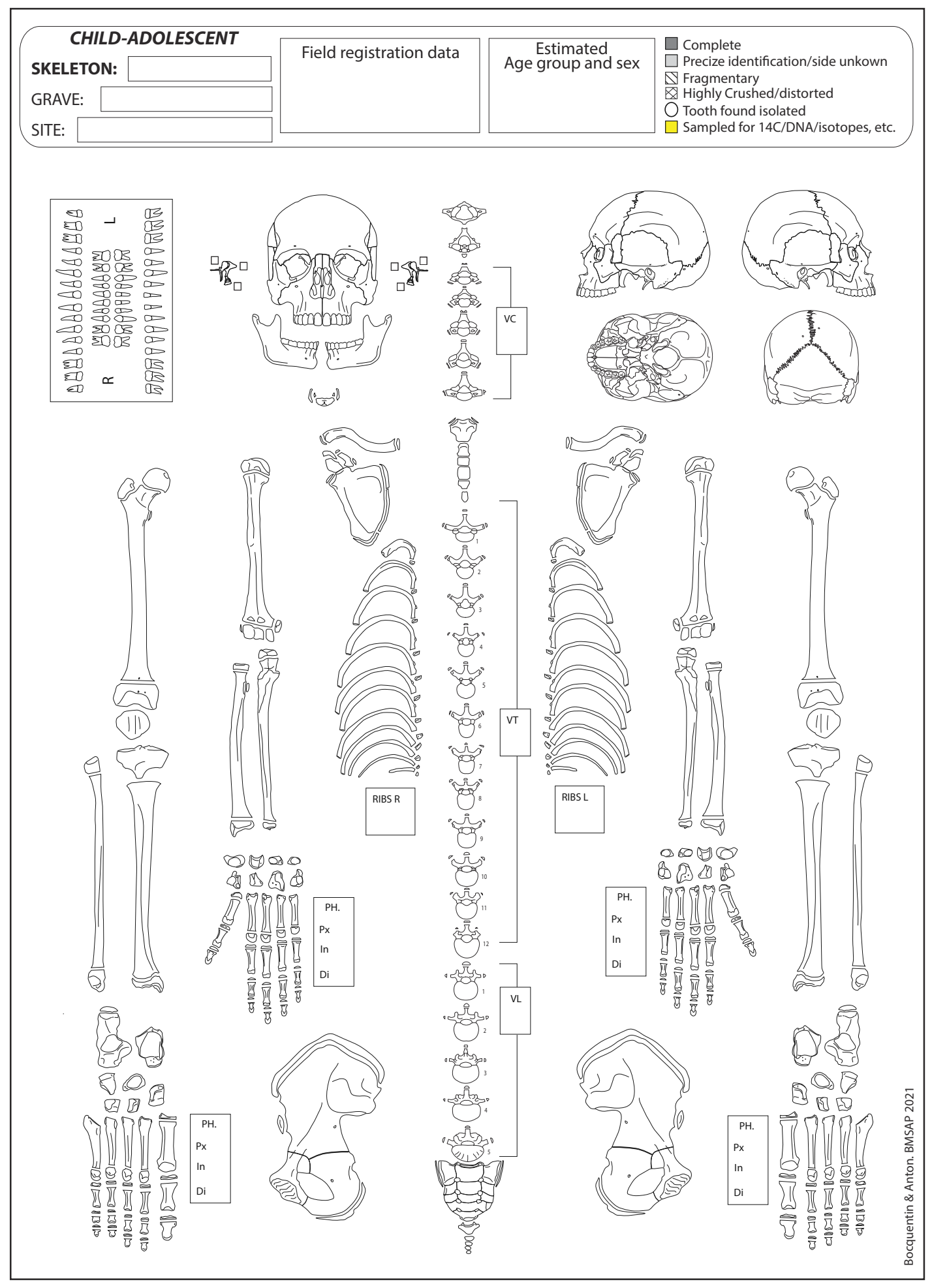




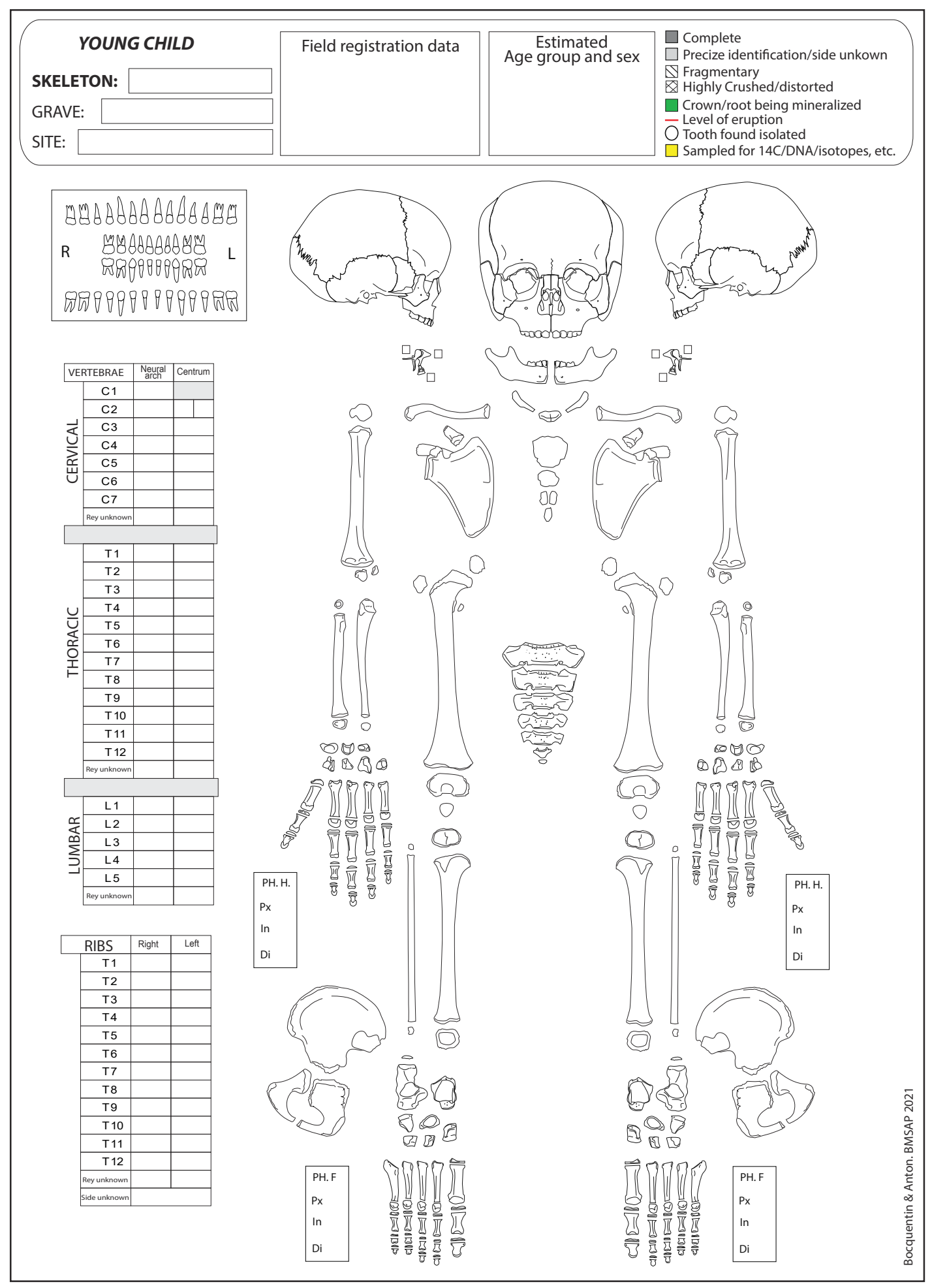




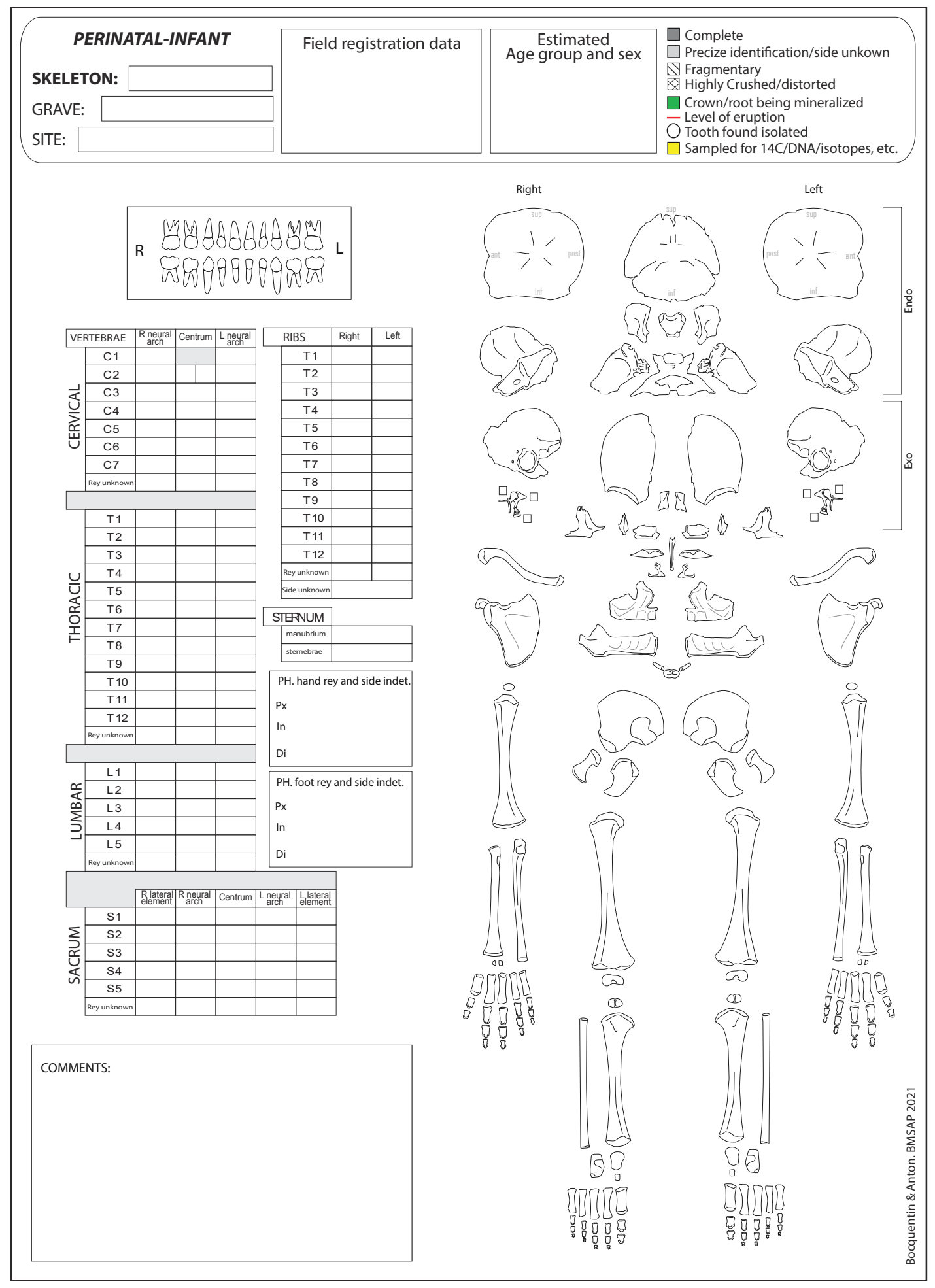


Appendix 2. Isolated bones visual inventory organized by categories:

axial bones and teeth, upper limbs, lower limbs

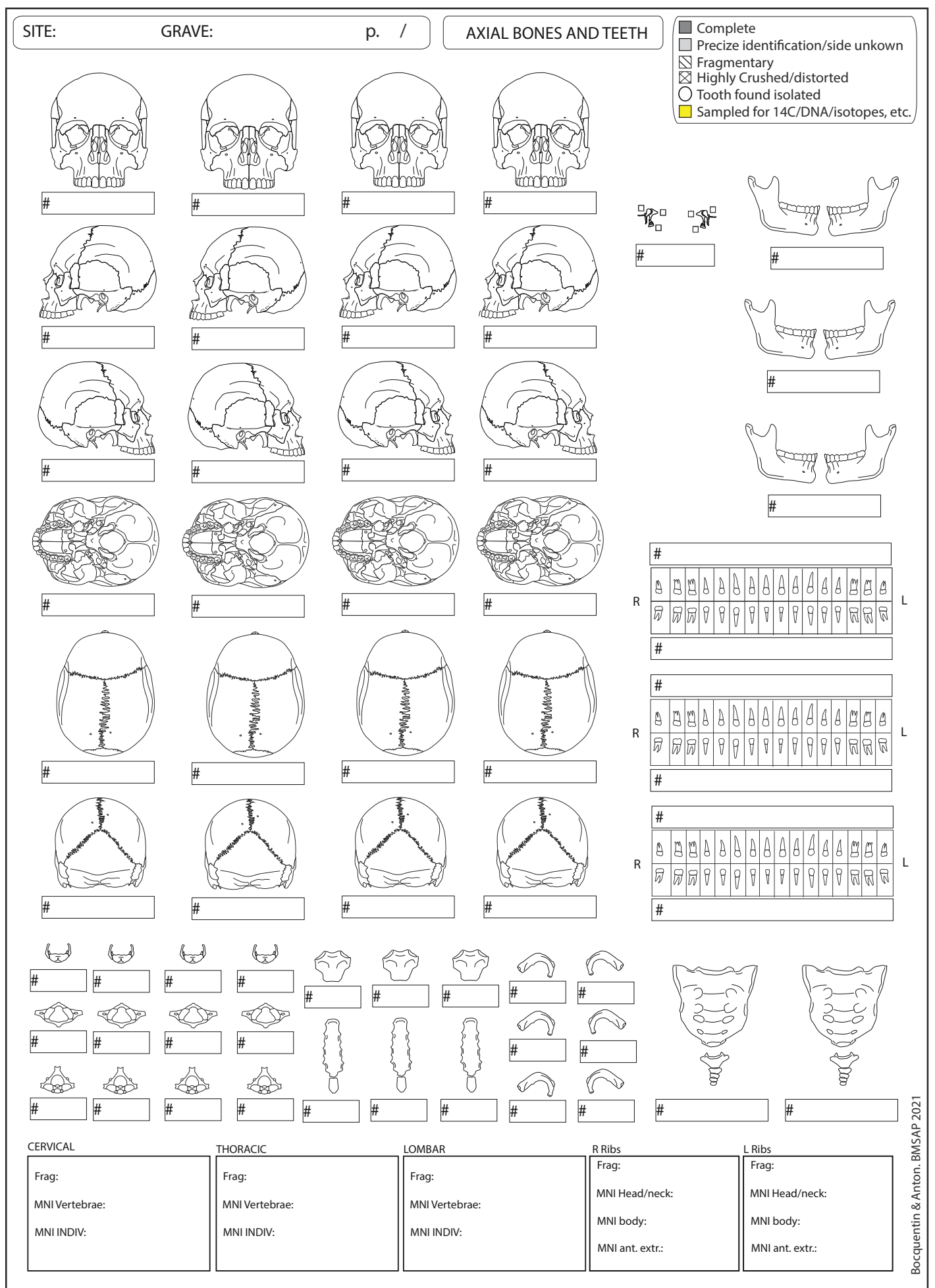




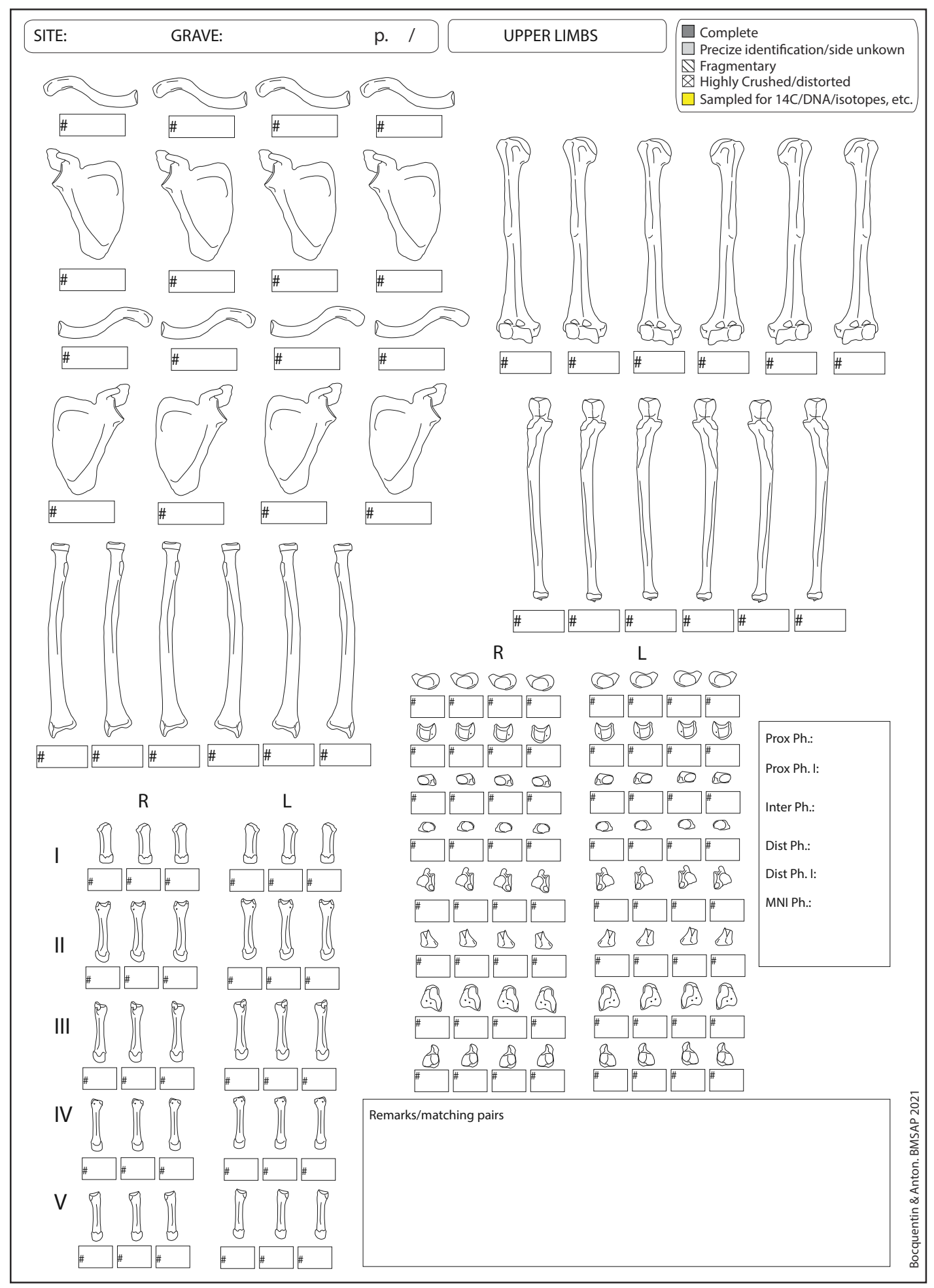




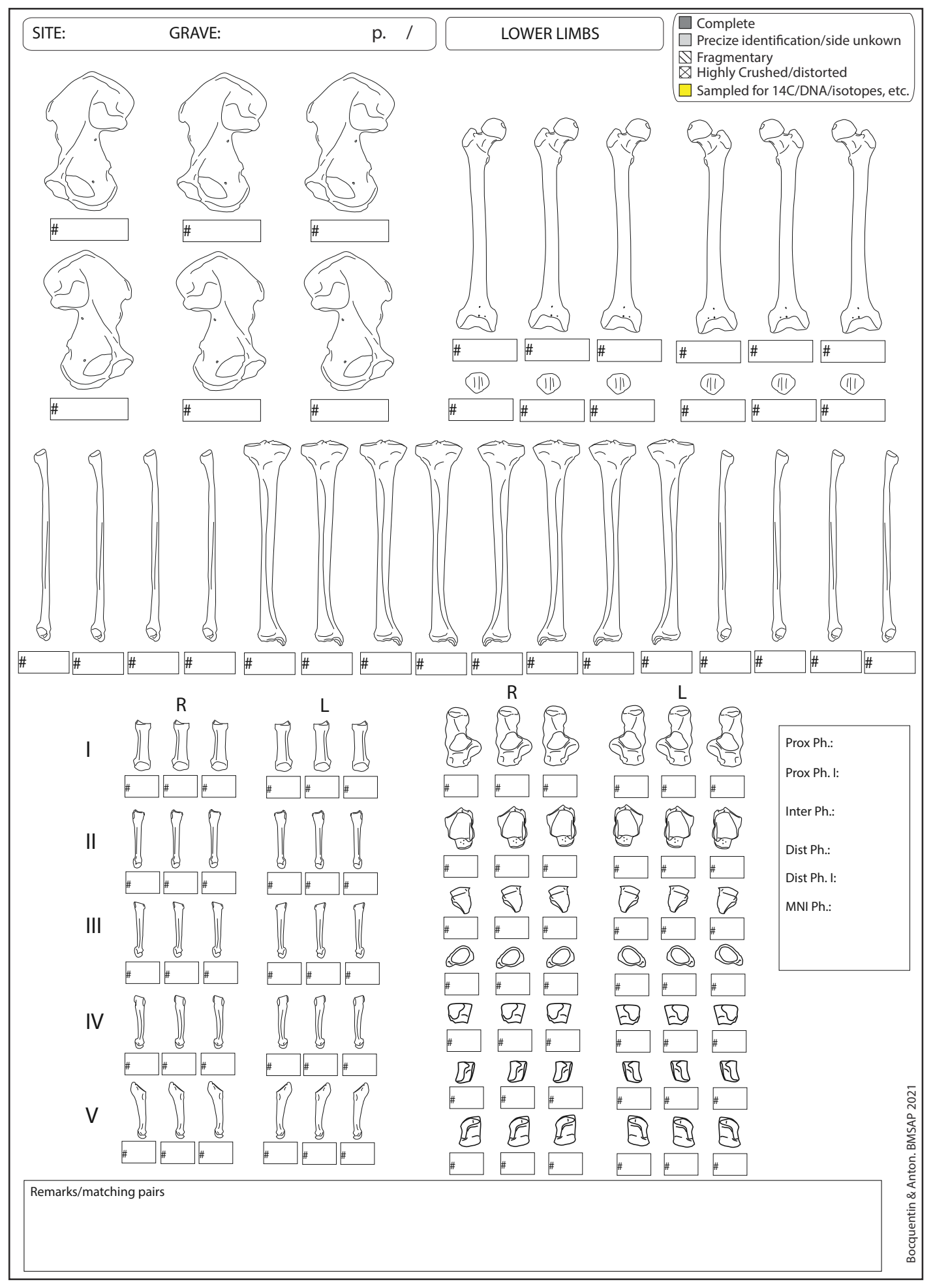


Appendix 3. Note templates organized as follows: first page for contextual information; second page for general data on the deposit of the corpse; third to fifth pages for the exposed side of the bones and taphonomical data on the skeleton (axial, upper limbs, lower limbs)

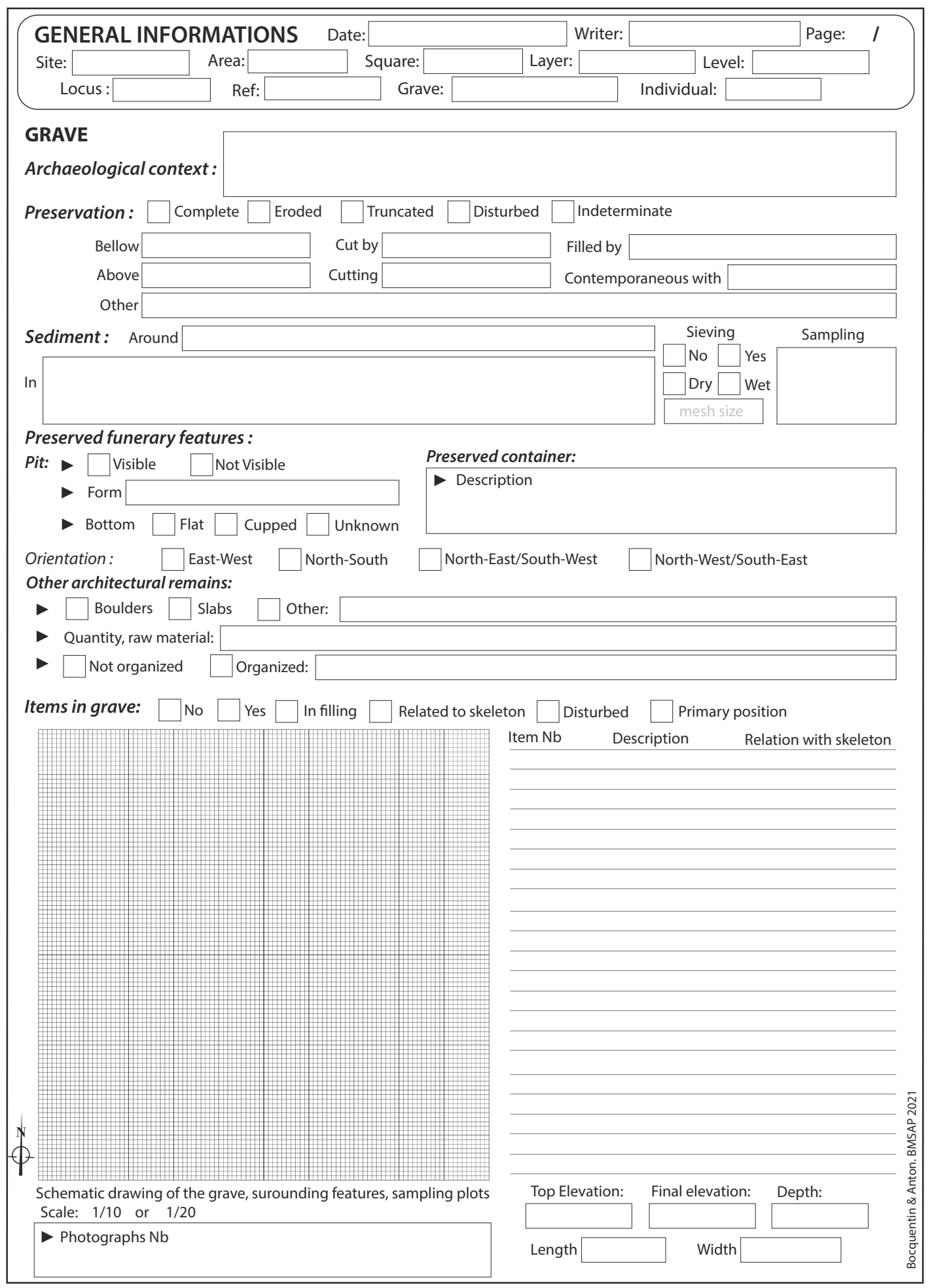









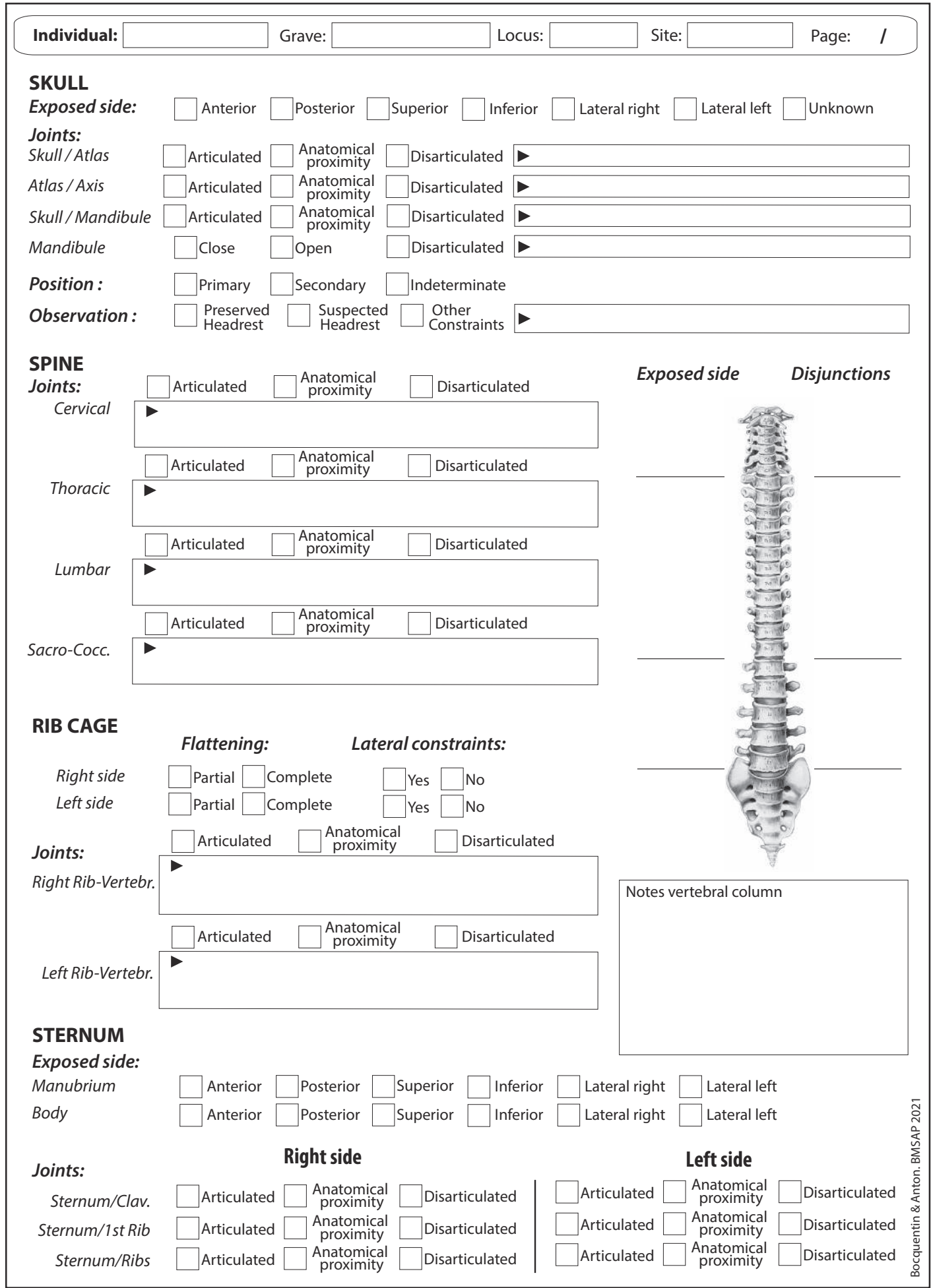




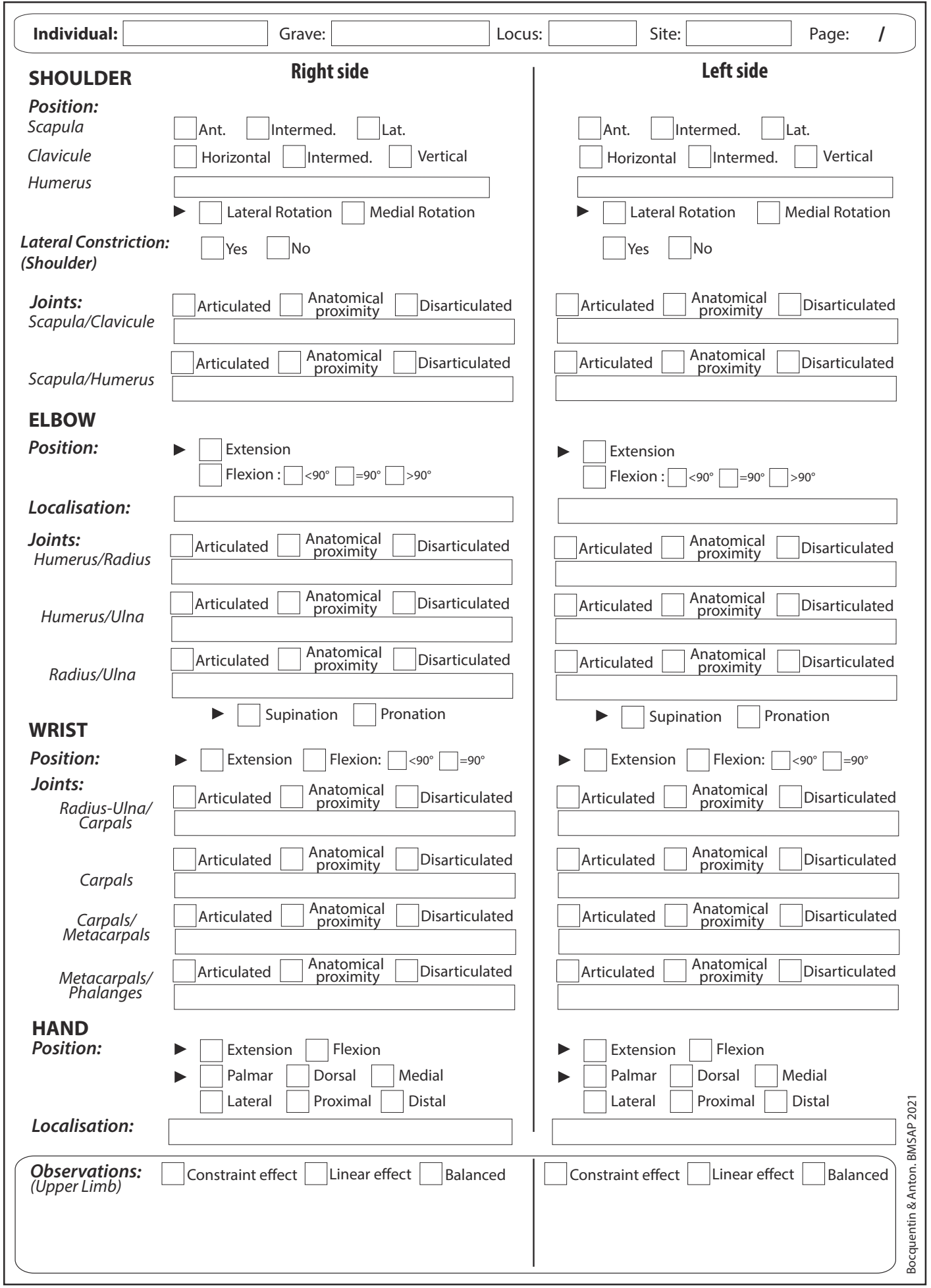




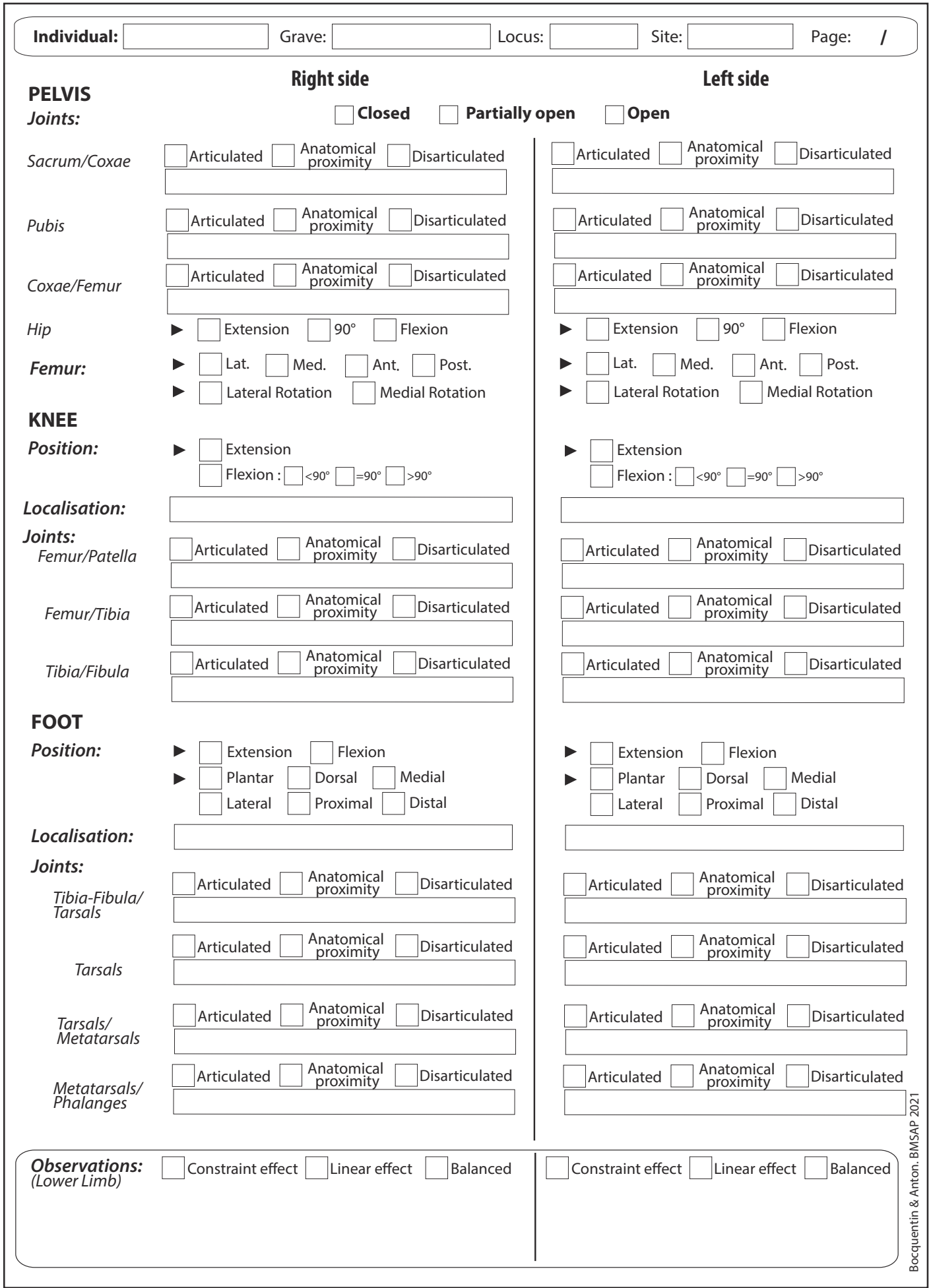

